\title{
PENINGKATAN KEMAMPUAN BETERNAK MELALUI "AKON- AKON KAMBING” BAGI WARGA RETRADASI MENTAL
}

\section{Muhammad Hanif ${ }^{1)}$, Raras Setyo Retno ${ }^{2)}$, Andista Candra Yusro ${ }^{3)}$}

${ }^{1}$ Program Magister Pendidikan Ilmu Pengetahuan Sosial, Program Pascasarjana, Universitas PGRI Madiun, Indonesia

${ }^{2}$ Pendidikan Guru Sekolah Dasar, FKIP, Universitas PGRI Madiun, Indoneesia

${ }^{3}$ Pendidikan Fisika, FKIP, Universitas PGRI Madiun, Indonesia

\begin{abstract}
Abstrak
Program pengabdian masyarakat ini bertujuan untuk meningkatkan keterampilan warga retardasi mental Dusun Sidowayah, Sidoharjo, Jambon, Ponorogo, Jawa Timur dalam beternak kambing. Program ini dilaksanakan mulai bulan April-November 2019. Sedangkan metodenya menggunakan akon-akon kambing. Metode ini merupakan teknik pemeliharaan kambing milik orang lain dan dianggapnya miliknya sendiri, bagi hasil dan pengelolaan bergulir. Hasilnya pelaksanaan kegiatan akon-akon ini, warga retardasi mental termotivasi dan keterampilannya beternak menjadi meningkat. Peningkatannya ditunjukan memberi perlakuan awal pada kambing peliharaannya sebesar $29,55 \%$, memberi perlakuan harian $11,93 \%$, memberi perlakuan musiman $20,5 \%$, dan memberi perlakuan akhir 22,5\%. Investasi program ini dalam 151 hari telah kembali modal dan mendapatkan keuntungan dalam bentuk anak kambing dan uang dari penjualan.
\end{abstract}

Keywords: akon-akon kambing; warga retradasi mental

\begin{abstract}
This community service program aims to improve the skills of mental retardation people in Sidowayah village, Sidoharjo, Jambon, Ponorogo, East Java in raising goats. This program was carried out from April to November 2019. The method used was "akon-akon kambing" (sharing goats). This method was used to raise goats that belong to other people, and it is considered their own, sharing their profits and rolling the management. As a result of the implementation of the method, mentally retarded citizens are motivated and their breeding skills also improved. The increase is shown by giving pre-treatment of domestic goats at $29.55 \%$, giving daily treatment at $11.93 \%$, giving a seasonal treatment at $20.5 \%$, and giving a final treatment at $22.5 \%$. This program investment during 151 days has returned capital and benefit in the form of goats and money from the sales.
\end{abstract}

Keywords: akon-akon kambing; mental retardation residents

Correspondence author: Muhammad Hanif, hanif@unipma.ac.id, Kota Madiun, and Indonesia 


\section{PENDAHULUAN}

Desa Sidoharjo Kecamatan Jambon Kabupaten Ponorogo merupakan salah satu desa yang dikategorikan sebagai "kampung idiot" karena banyak warganya yang mengalami retardasi mental. Desa lainnya yaitu Desa Krebet, Karangpatihan, dan Pandak. Sebutan "kampung idiot" tersebut sebenarnya tidak tepat karena kata idiot secara akademis diperuntukan bagi retardasi mental (keterbelakangan mental= tunagrahita) berat. Dalam psikologi klinis, orang yang mengalami retardasi mental adalah kelainan atau kelemahan jiwa dengan inteligensi yang kurang (subnormal) sejak masa perkembangan. Biasanya terdapat perkembangan mental yang kurang secara keseluruhan, tetapi gejala yang utama adalah intelegensi yang terbelakang (Maramis 2005; Sularyo and Kadim 2010).

Kasus retradasi mental pada warga di dusun Sidowayah Desa Sidoharjo ditemukan pertama kali pada 1970 (Hanif 2017). Hal tersebut disebabkan oleh berbagai faktor, antara lain; gizi buruk, sarana prasarana dan pelayanan kesehatan yang tidak memadai, air tanah yang dikonsumsi sangat rendah kadar yodiumnya dan ada juga yang berpendapat kejadian ini karena kutukan. Tidak semua warga yang mengalami retradasi mental "kampong idiot" adalah idiot, dan tidak semua warga yang cacat mengalami gangguan mental (Nevid, Rathus, Greene, 2007). Dari penelitian yang dilakukan sebelumnya ditemukan bahwa di kampung tersebut selain warga retardasi mental terdapat juga warga yang mengalami kecacatan lain, diantaranya cacat fisik dan sakit jiwa. Mereka itu dikategorikan sebagai Orang Dengan Kecacatan (ODK). Banyak warga yang mengalami retardasi mental di Desa Sidoharjo mulai terjadi 1970-an. Hal tersebut disebabkan oleh berbagai faktor, antara lain; gizi buruk, sarana prasarana dan pelayanan kesehatan yang tidak memadai, air tanah yang dikonsumsi sangat rendah kadar yodiumnya, dan ada juga yang berpendapat kejadian ini karena kutukan (Hanif 2014).

Dalam kehidupan bersama dengan lingkungan sosial yang diwarnai banyaknya orang yang mengalami retardasi mental tersebut, keluarga dan masyarakat di lingkungan sekitar pada umumnya tidak menyembunyikan, tidak menutupi kondisi warga retardasi mental. Mereka memberi bantuan (pangan, sandang, dan papan), namun belum memfasilitasi warga retardasi mental untuk mengembangkan diri dan mendorong beradaptasi dengan lingkungan (Hanif 2014). Hal ini disebabkan oleh banyak orangtua/keluarga dan warga masyarakat di lingkungan sekitar yang belum memiliki pengetahuan dan pemahaman yang memadai tentang penanganan orang retardasi mental. Selain itu juga disebabkan oleh kondisi ekonomi yang realtif miskin. Sehingga orangtua/keluarga dan warga masyarakat walaupun menerima warga retardasi mental tetapi kesannya lebih pada "pembiaran". Keinginan warga masyarakat di lingkungan sekitar untuk turut serta memberdayakan warga retardasi mental sering kali terkendala pada strategi dan dana pemberdayaan. Hal tersebut dimaklumi karena masih banyak warga masyarakat yang hidup di bawah garis kemiskinan. Hal itu ditunjukkan dari 1.609 keluarga/rumah tangga terdapat 944 rumah tangga miskin dan 495 rumah tangga rentan miskin (BPS, 2018).

Oleh karena itu perlu adanya program kegiatan dengan tujuan untuk meningkatkan keterampilan bekerja untuk warga kampung Sidowayah Desa Sidoharjo Kecamatan Jambon Kabupaten Ponorogo. Satu di antaranya dengan akon-akon kambing. Akon-akon (bahasa Jawa Ngoko yang artinya dianggap). Akon-akon juga dipadankan dengan kata "digaduh" (bahasa Jawa yang artinya memelihara milik orang lain dengan sistem bagi hasil). Dengan demikian yang dimaksud akon-akon ternak yaitu ternak milik orang lain 
yang dipelihara seperti miliknya sendiri dan dikelola secara bergulir. Akon-akon kambing merupakan teknik atau metode memelihara kambing dengan sistem bagi hasil. Kambing milik orang lain atau pihak lain dipelihara seperti miliknya sendiri (Hanif and Retno 2019).

Program pemberdayaan ini didasarkan pada teori dan data empiris bahwa walaupun orang yang mengalami banyak keterbatasan namun masih memiliki potensi yang dapat diberdayakan (Durand and Barlow 2007). Dalam teori pembelajaran sosial disampaikan bahwa tindakan keterampilan hidup manusia dibentuk dengan memberi lebih banyak penekanan pada efek-efek dari isyarat-isyarat pada perilaku, dan pada proses-proses mental internal dengan menggunakan penjelasan-penjelasan penguatan eksternal dan penjelasan-penjelasan kognitif internal untuk memahami bagaimana aktivitas orang lain (Bandura 1977, 1994). Sedangkan ternak kambing dijadikan media pemberdayaannya karena (1) kebutuhan daging kambing setiap tahunnya terus mengalami peningkatan (aqiqoh, qurban, dan lain-lainya), (2) kambing tidak membutuhkan perawatan yang rumit, (4) kambing mudah berkembang biak (masa kehamilan sekitar 5 atau 151 hari), (4) rumput dan tumbuhan pakan kambing tersedia di lingkungan sekitar (Farm 2018; Prabowo 2010; Rusdiana, Praharani, and Adiati 2014).

Program meningkatkan keterampilan beternak ini dirancang dan dikembangkan dengan merujuk penjelasan Asian Development Bank atau ADB (Mulyawati, Mardiningsih, and Satmoko 2016; Riyadhi, Rizal, and Wahdi 2017; Zubaedi 2014) bahwa kegiatan pemberdayaan termasuk pemandirian ekonomi perlu menampilkan kegiatan yang berkarakteritik: (1) berbasis lokal, (2) berorientasi pada peningkatan kesejahteraan, (3) berbasis kemitraan, (4) holistik, dan (5) berkelanjutan. Sehingga pemandirian ekonomi warga retardasi mental ini direncanakan dan dilaksanakan dengan melibatkan sumber daya lokal, baik sumber daya alam maupun sumber daya sosialnya.

\section{METODE PELAKSANAAN}

Program pengabdian masyarakat ini dilaksanakan di Dusun Sidowayah Desa Sidoharjo Kecamatan Jambon Kabupaten Ponorogo Provisinsi Jawa Timur. Dalam pelaksanaannya, tim pengabdian masyarakat bermitra dengan Forum Sidowayah Bangkit (FSB). Sedangkan waktu pelaksanaannya mulai bulan April 2019 sampai dengan November 2019. Metode yang digunakan sebagai berikut:

1. Sosialisasi program akon-akon kambing

Pemberdaya (tim PKMS dan mitra/FSB) melakukan sosialisasi program akon-akon kambing kepada warga retardasi, keluarga dan warga di lingkungan sekitar.

2. Penyusunan satuan program kegiatan

Pemberdaya menyusun satuan program kegiatan (awal, harian, musiman, dan akhir).

3. Pelatihan pemeliharaan kambing

Pemberdaya melatih warga retardasi mental beternak kambing terutama dalam perlakuan awal, harian, musiman, dan akhir.

4. Pengadaan kambing indukan atau bakalan.

Pemberdaya mengadakan kambing indukan atau bakalan dari dana yang tersedia dengan menyesuaikan jenis kambing yang diminati oleh calon pengakon. 
5. Pemeliharaan kambing indukan atau bakalan

Warga retardasi mental pengakon tahap 1 memelihara kambing indukan. Dalam tahap ini, pemberdaya bekerja sama dengan keluarga dan warga normal yang ada di sekitar warga retardasi mental melalukan pendampingan, monitoring, dan evaluasi.

6. Pembagian anak kambing

Pemberdaya mengambil anak kambing ke pengakon jika kambing yang diakon sudah beranak kedua kalinya dan anaknya lebih satu. Anak kambing yang diambil tersebut ketika sudah tidak lagi menyusu pada induknya. Anak tersebut kemudian digulirkan untuk dikembangbiakan atau dibesarkan dengan sistem bagi hasil.

7. Pemindahan kambing indukan

Pemberdaya memindahkan kambing indukan yang sudah beranak kedua kalinya untuk diberikan kepada warga retardasi mental lainnya yang belum memelihara kambing (pengakon ke-2). Kegiatan ini terus berlanjut dan bergulir.

8. Penjualan kambing indukan

Jika kambing indukan tidak lagi produktif maka pemberdaya menjualnya. Hasil penjualannya digunakan untuk membeli kambing indukan atau bakalan baru dan selanjutnya digulirkan kepada warga retardasi mental yang belum mendapat giliran sebelumnya.

9. Penjualan kambing bakalan

Pemberdaya melakukan evaluasi terhadap kambing bakalan yang di-akon-akon. Jika dievaluasi sudah layak dan situasi serta kondisi tepat maka pemberdaya membuat kesepakan dengan pengakon untuk menjualnya. Laba hasil penjualan (harga kambing ketika dijual dikurangi harga kambing ketika dibeli) dibagi dua. Lima puluh persen untuk pengakon.

10. Pembelian kambing indukan atau bakalan baru

Dana/modal awal ditambah laba dari usaha kemudian digunakan untuk membeli kambing indukan atau bakalan yang baru. Kemudian menggulirkan kambing indukan dan bakalan yang baru dengan model seperti semula kepada warga retardasi mental yang lain atau giliran berikutnya.

Teknik akon-akon kambing ini dapat digambarkan seperti di bawah ini:

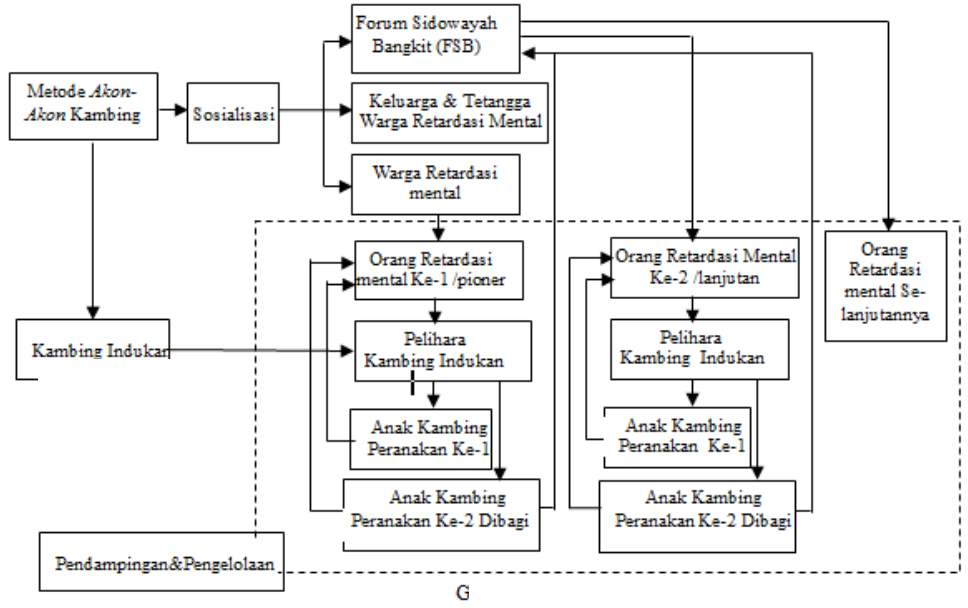

Gambar 1 Tahapan Akon-akon Kambing Betina 


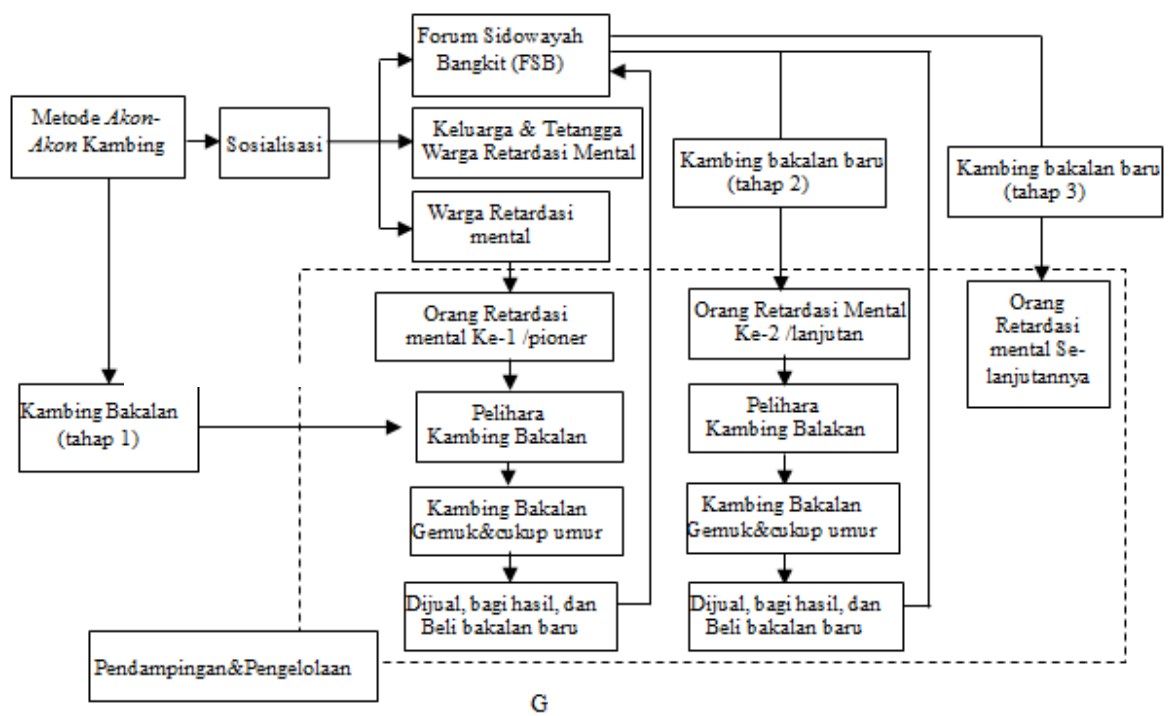

Gambar 2 Tahapan Akon-akon Kambing Jantan

Metode pengambilan data dalam evaluasi pelaksanakan program menggunakan teknik observasi, wawancara, dan pecatatan dokumen. Sedangkan analisisnya menggunakan statistik deskriptif.

\section{HASIL DAN PEMBAHASAN}

Tim Pengabdi mensosialisasikan program akon-akon kambing kepada para warga retardasi mental (32 orang), keluarga retardasi mental, dan para pendamping (mitra FSB).

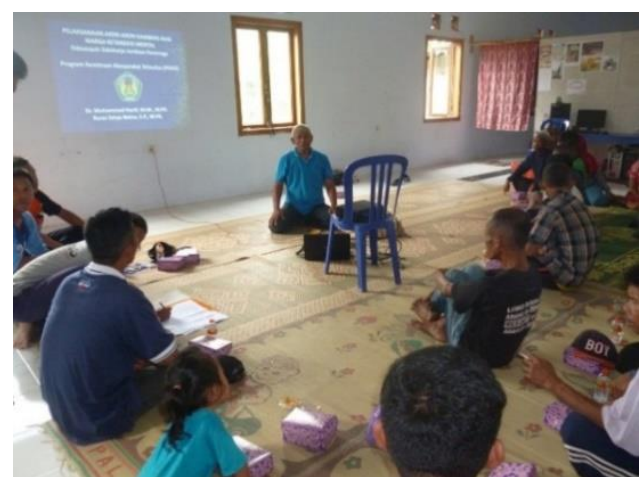

Gambar 3. Sosialisasi Program Akon-akon Kambing kepada warga retardasi mental dan keluarganya

Langkah selanjutnya, Tim Pengabdi dan Mitra menentukan para pengakon awal sebanyak 12 orang yang terdiri 9 orang retardasi mental debil/ringan dan 3 orang retardasi mental imbesil/sedang. Para pengakon diinterview dan diobservasi kepeminatan jenis kelamin kambing yang diakon-akon. Kemudian tim membeli kambing berjumlah 12 ekor. Jumlah tersebut menyesuaikan dana yang tersedia. 


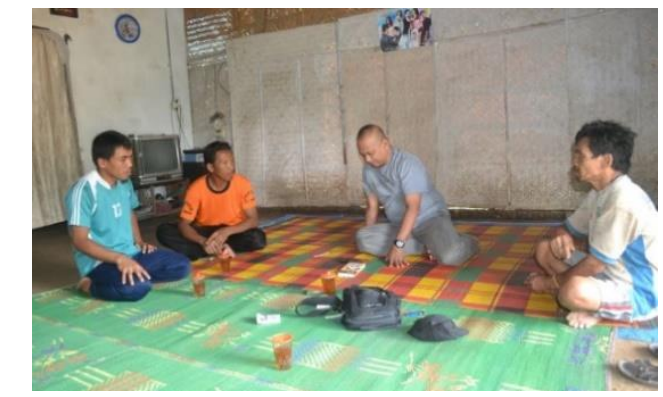

Gambar 4 Interview dengan Poniran (pengakon)

Para pengakon kemudian memelihara kambing didampingi seorang tenaga pendamping. Kegiatannya meliputi:

1. Memberi perlakuan awal pada kambing yang diakon berupa tindakan memberi tanda pengenal, vitamin, pakan dan minum,

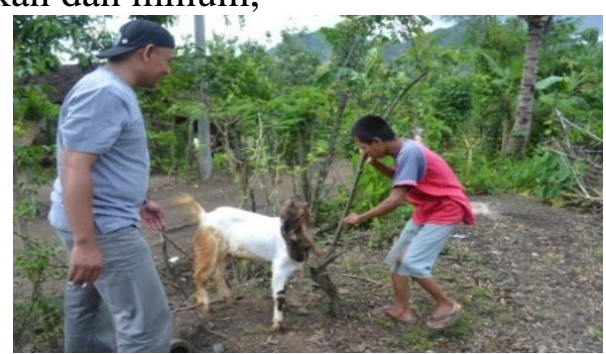

Gambar 5 Soyo memberian perlakuan awal

2. Memberi perlakuan harian pada kambing yang diakon berupa mencari pakan, memberi pakan, menyediakan minum, memberi minum, memandikan, menjemur, dan membersihkan kandang,

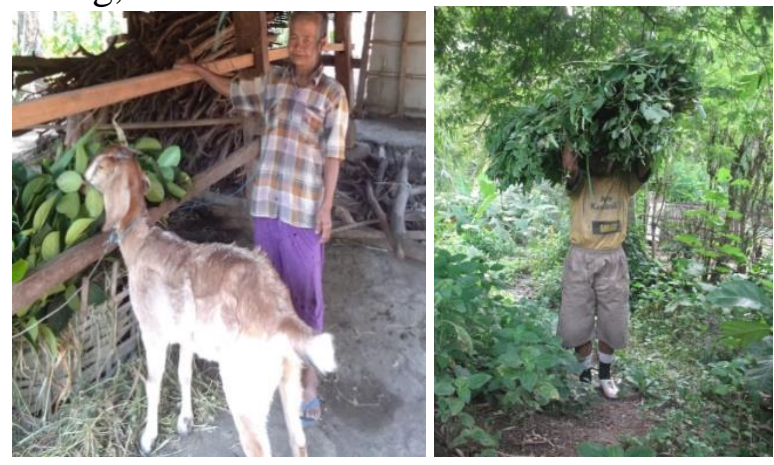

Gambar 6. Surip sedang memberi pakan dan Senin mencari pakan kambing

3. Memberi perlakuan musiman pada kambing yang diakon berupa pembersihan kuku,

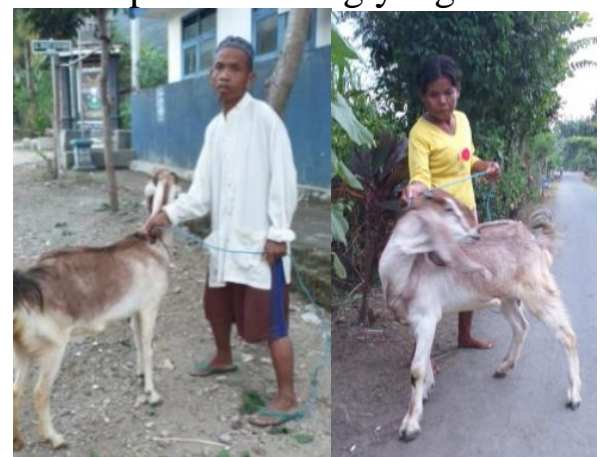

Gambar 6. Meseni dan Toinem sedang membersihkan kambing yang diakon-akon 
4. Memberi perlakuan akhir berupa proses beranak, membagi anak, dan membagi hasil usaha akon-akon.

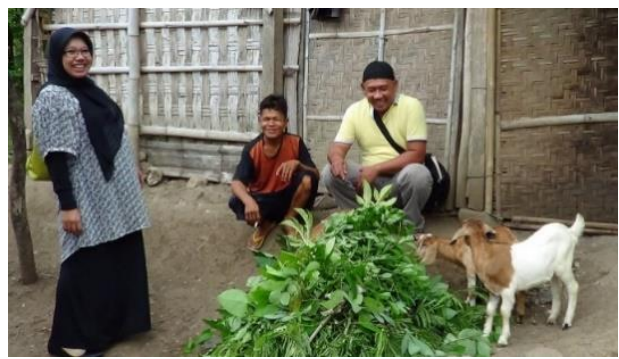

Gambar 7. Tim pengabdi berdiskusi dengan Meseno tentang kambing yang diakonnya telah beranak berikut:

Hasil evaluasi yang dilaksanakan dalam kurun waktu pelaksanaan program sebagai

Memberi perlakuan awal pada kambing yang diakon-akon.

Dalam kurun waktu dua minggu pendampingan di bulan April 2019, keterampilan warga retardasi mental dalam memberi perlakuan awal pada kambing yang diakonnya meningkat $29,55 \%$. Hal tersebut tercantum pada gambar di bawah ini

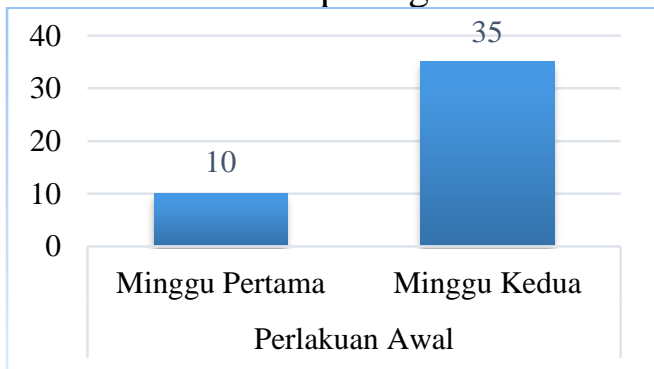

Gambar 8. Kemampuan memberi perlakuan awal pada kambing yang diakon-akon

\section{Memberi perlakuan harian pada kambing yang daikon}

Dalam kurun waktu tiga bulan (Mei-Juli 2019) pendampingan, keterampilan warga retardasi mental dalam memberi perlakuan harian pada kambing yang diakonnya meningkat $11,93 \%$. Hal tersebut tercantum pada gambar di bawah ini

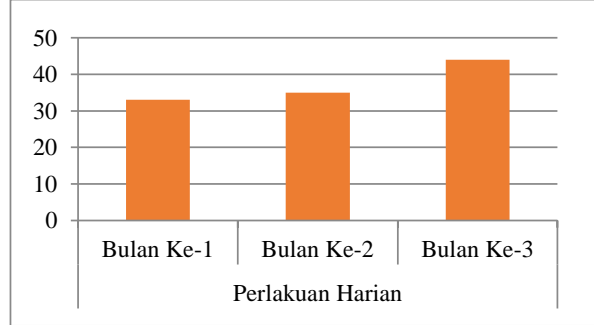

Gambar 9. Kemampuan memberi perlakuan harian pada kambing

\section{Memberi perlakuan musiman pada kambing yang diakon}

Dalam kurun waktu tiga minggu (September 2019) pendampingan, keterampilan warga retardasi mental dalam memberi perlakuan musiman pada kambing yang diakonnya meningkat $20,5 \%$. Hal tersebut tercantum pada gambar di bawah ini 


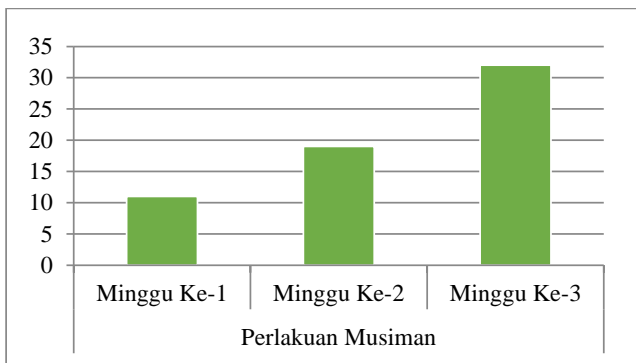

Gambar 10. Kemampuan memberi perlakuan musiman pada kambing yang diakon-akon

\section{Memberi perlakuan akhir pada kambing yang diakon-akon}

Penilaian akhir dilaksanakan pada bulan Oktober 2019. Hasil evaluasi menggambarkan keterampilan warga retardasi mental dalam memberi perlakuan akhir pada kambing yang diakonnya meningkat $22,5 \%$. Hal tersebut tercantum pada gambar di bawah ini

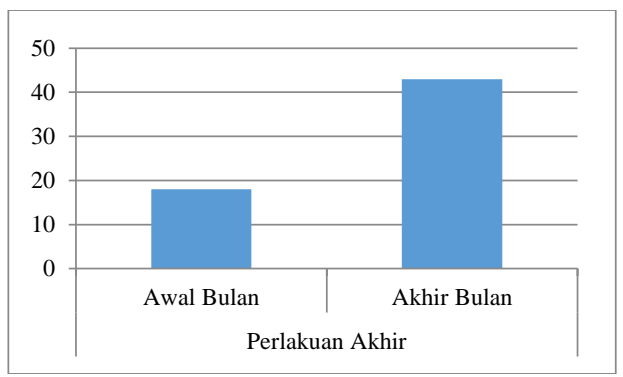

Gambar 11. Kemampuan memberi perlakuan akhir pada kambing yang diakon-akon

Pada bulan November 2019 secara finansial para pengakon sudah bisa menikmati hasilnya. Pada kelompok pengakon kambing betina ada 2 orang pengakon yang kambingnya sudah beranak. Masing-masing beranak 2 ekor. Sedangkan pada kelompok kambing jantan ada 6 orang pengakon yang kambingnya sudah terjual dan untung. Sedangkan 3 orang pengakon belum berhasil sebab peranakan kambingnya mati. Namun mereka tetap semangat untuk beternak atas hubungan kolegial dengan sesama orang retardasi mental dan dengan warga normal yang ada di lingkungan sekitarnya.

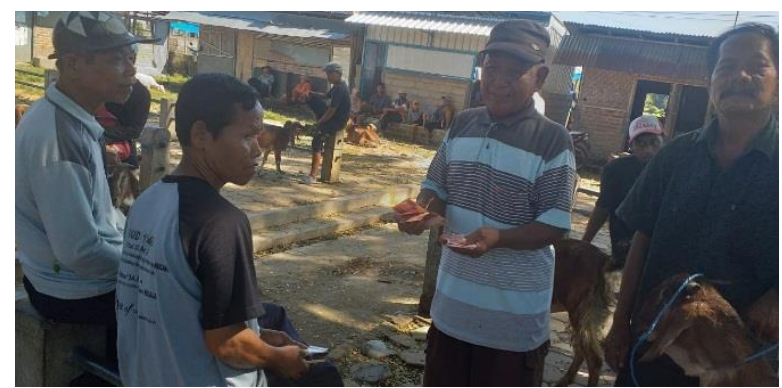

Gambar 12. Senin (pendamping) sedang traksasi penjualan kambing jantan dan membagi keuntungannya

Peningkatan keterampilan warga retardasi mental dalam beternak kambing sebagaimana dipaparkan di atas merupakan tingkah laku yang ditampilkan orang dalam situasi sosial dengan manusia yang lain merupakan satu pola yang relatif menetap yang diperlihatkan oleh individu di dalam memelihara. Hal tersebut sejalan teori belajar Bandura (1977) dan (Skinner, 2013) bahwa tindakan-keterampilan dapat dilakukan dengan cara; (a) Pembiasaan atau (condisioning) yaitu warga retardasi mental dibiasakan menjalankan aktivitas beternak, (b) Pengertian (insight) yaitu warga retardasi mental 
diberi pengertian, pemahaman, dan informasi tentang arti penting, manfaat, dan segala sesuatu yang berkaitan dengan beternak kambing, (c) Pemodelan (modelling) yaitu warga retardasi mental diberi contoh tentang memelihara kambing, (d) Penguatan (reinforcement) yaitu warga retardasi mental agar melakukan aktivitas beternak secara berkelanjutan diperlukan hadiah berupa bagi hasil peranakan atau pembagian keuntungan hasil penjualannya.

Program "akon-akon kambing" menjadi sumber inspirasi dan motivasi diantara warga di lingkungan sekitarnya untuk turut serta ambil bagian dalam memberdayakan warga retardasi mental. Salah satunya dengan memberi modal awal dan/atau binatang yang diakon.

\section{SIMPULAN}

Akon-akon kambing berhasil meningkatkan keterampilan warga retardasi mental (debil dan imbesil) Dusun Sidowayah Desa Sidoharjo Kecamatan Jambon Kabupaten Ponorogo dalam beternak kambing. Peningkatan keterampilan warga retardasi mental tersebut ditunjukkan dalam berbagai jenis kegiatan, yaitu keterampilan memberi perlakuan awal, harian, musiman, dan akhir. Keterampilan memberi perlakuan awal meningkat sebesar $29,55 \%$, keterampilan memberi perlakuan harian meningkat sebesar $11,93 \%$, keterampilan memberi perlakuan musiman meningkat sebesar $20,5 \%$, dan keterampilan memberi perlakuan akhir meningkat sebesar 22,5. Investasi yang ditanamkan pada program ini dalam waktu 151 hari sudah kembali modal dan mendapatkan laba yang berupa peranakan kambing dan uang hasil penjualan. Akon-akon kambing ini menjadi spirit warga retardasi mental Dusun Sidowayah untuk memelihara, membesarkan, dan mengembang-biakan kambing. Hasilnya tidak terbatas pada aspek ekonomi saja tetapi juga keterampilan beternak kambing.

\section{UCAPAN TERIMAKASIH}

Pengabdi menyampaikan terimakasih kepada Direktorat Penguatan Riset dan Pengabdian Masyarakat, Kemenristekdikti, bapak/ibu pendamping lapangan, keluarga warga retardasi mental dan masyarakat kampung Sidowayah atas segala bantuannya sehingga program ini berjalan sesuai harapan dan hasilnya baik.

\section{DAFTAR PUSTAKA}

Bandura, A. (1977) Social Learning Theory. New Jersey: Prentise Hall.

Bandura, Albert. (1994). "Self-Efficacy." Pp. 71-78 in Encyclopedia of human behavior (Vol. New York: Academic Press.

BPS. (2018). Kabupaten Bireuen Dalam Angka 2018. edited by B. P. S. K. Bireuen. Bireuen: Badan Pusat Statistik Bireuen. 
Durand, M. .., and D. H. Barlow. (2007). Psikologi Abnormal. edited by Helly Prajitno Soetjipto dan Sri Mulyantini Soetjipto. Yogyakarta: Pustaka Pelajar.

Farm, Mitra Tani. (2018). Untung Dari Bisnis Domba Dan Kambing. Jakarta: PT ArgoMedia Pustaka.

Hanif, Muhammad. (2014). Meneropong Kampung Idiot, Perilaku Sosial Terhadap Warga Retardasi Mental Sidoharjo Dan Krebet. Madiun: Institut Press.

Hanif, Muhammad. (2017). "Social Community Behavior Toward Residents With Mental Retardation At \&quot;Idiot Village\&quot; Sidoharjo Jambon Ponorogo." IOSR Journal Of Humanities And Social Science (IOSR-JHSS 22(8):41-48.

Hanif, Muhammad, and R. S. Retno. (2019). "Akon-Akon Kambing As A Methods Of Empowering Disability: Local Wisdom Studiese." International Journal of Scientific \& Technology Research 8(11):427-33.

Maramis, W. F. (2005). Catatan Ilmu Kedokteran Jiwa. Surabaya: Airlangga University Press.

Mulyawati, I. M., Mardiningsih, and S. Satmoko. (2016.) "Pengaruh Umur, Pendidikan, Pengalaman Dan Jumlah Ternak Peternak Kambing Terhadap Perilaku Sapta Usaha Beternak Kambing Di Desa Wonosari Kecamatan Patebon.” Agromedia Vol 34, No:85-90.

Nevid, J.S., Rathus, S., Greene, B. (2007). Psikologi Abnormal Jilid 2. 5th ed. edited by Ratri Medya dan Kristiaji. Jakarta: Airlangga.

Prabowo, Agung. (2010). "Petunjuk Teknis Budidaya Ternak Kambing (Materi Pelatihan Aribisnis Bagi KMPH).” (51):1-13.

Riyadhi, Muhammad, Muhammad Rizal, and Anis Wahdi. (2017). "Diseminasi Teknologi Inseminasi Buatan Menggunakan Semen Kambing Peranakan Etawa ( PE ) Dengan Pengencer Air Kelapa Muda Dan Kuning Telur Di Kecamatan Bati Bati Kabupaten Tanah Laut Kalimantan Selatan." Jurnal Pengabdian Kepada Masyarakat 1(2):125-30.

Rusdiana, S., L. Praharani, and U. Adiati. (2014). "Prospek Dan Strategi Perdagangan Ternak Kambing Dalam Merebut Peluang Pasar Dunia." Agriekonomika 3(2):203-22.

Skinner, B. F. (1996). Science and Human Behaviour. New York: McMillan.

Sularyo, Titi Sunarwati, and Muzal Kadim. (2010). "Retradasi Mental.” Sari Pediatri 2(3):170-77.

Zubaedi. (2014). Pengembangan Masyarakat, Wacana Dan Praktik. Jakarta: Kencana Prenadamedia Group. 